\title{
Ion Exchange Conceptual Design for Treating Seven Technical Area Sumps with Elevated Levels of Copper and Zinc
}

by

L. N. Oji

Westinghouse Savannah River Company

Savannah River Site

Aiken, South Carolina 29808

R. A. Hane

DOE Contract No. DE-AC09-96SR18500

This paper was prepared in connection with work done under the above contract number with the U.S.

Department of Energy. By acceptance of this paper, the publisher and/or recipient acknowledges the U.S. Government's right to retain a nonexclusive, royalty-free license in and to any copyright covering this paper, along with the right to reproduce and to authorize others to reproduce all or part of the copyrighted paper. 


\section{DISCLAIMER}

This report was prepared as an account of work sponsored by an agency of the United States Government. Neither the United States Government nor any agency thereof, nor any of their employees, makes any warranty, express or implied, or assumes any legal liability or responsibility for the accuracy, completeness, or usefulness of any information, apparatus, product, or process disclosed, or represents that its use would not infringe privately owned rights. Reference herein to any specific commercial product, process, or service by trade name, trademark, manufacturer, or otherwise does not necessarily constitute or imply its endorsement, recommendation, or favoring by the United States Government or any agency thereof. The views and opinions of authors expressed herein do not necessarily state or reflect those of the United States Government or any agency thereof.

This report has been reproduced directly from the best available copy.

Available to DOE and DOE contractors from the Office of Scientific and Technical Information, P.O. Box 62, Oak Ridge, TN 37831; prices available from (615) 576-8401.

Available to the public from the National Technical Information Service, U.S. Department of Commerce, 5285 Port Royal Road, Springfield, VA 22161. 


\section{DISCLAIMER}

Portions of this document may be illegible in electronic image products. Images are produced from the best available original document. 
WESTINGHOUSE SAVANNAH RIVER COMPANY

SAVANNAH RIVER TECHNOLOGY CENTER

WSRC-TR-98-00453

ION EXCHANGE CONCEPTUAL DESIGN FOR TREATING SEVEN TECHNICAL AREA SUMPS WITH ELEVATED LEVELS OF COPPER AND ZINC (U)

Authors: Lawrence N. Oji and R. A. Hane, 773-43A

Report Date: December 10, 1998

Westinghouse Savannah River Company Savannah River Site Aiken, SC 29808

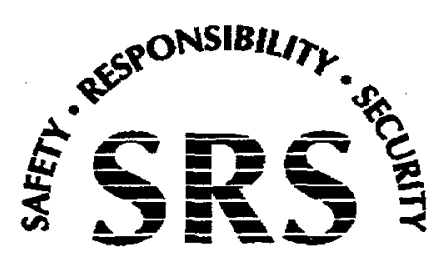


WESTINGHOUSE SAVANNAH RIVER COMPANY

SAVANNAH RIVER TECHNOLOGY CENTER

WSRC-TR-98-00453

ION EXCHANGE CONCEPTUAL DESIGN FOR TREATING SEVEN TECHNICAL AREA SUMPS WITH ELEVATED LEVELS OF COPPER AND ZINC (U)

TO: $\quad$ M. S. Boerste, 773-43A

FROM: L. N. Oji and R. A. Hane, 773-43A

Author
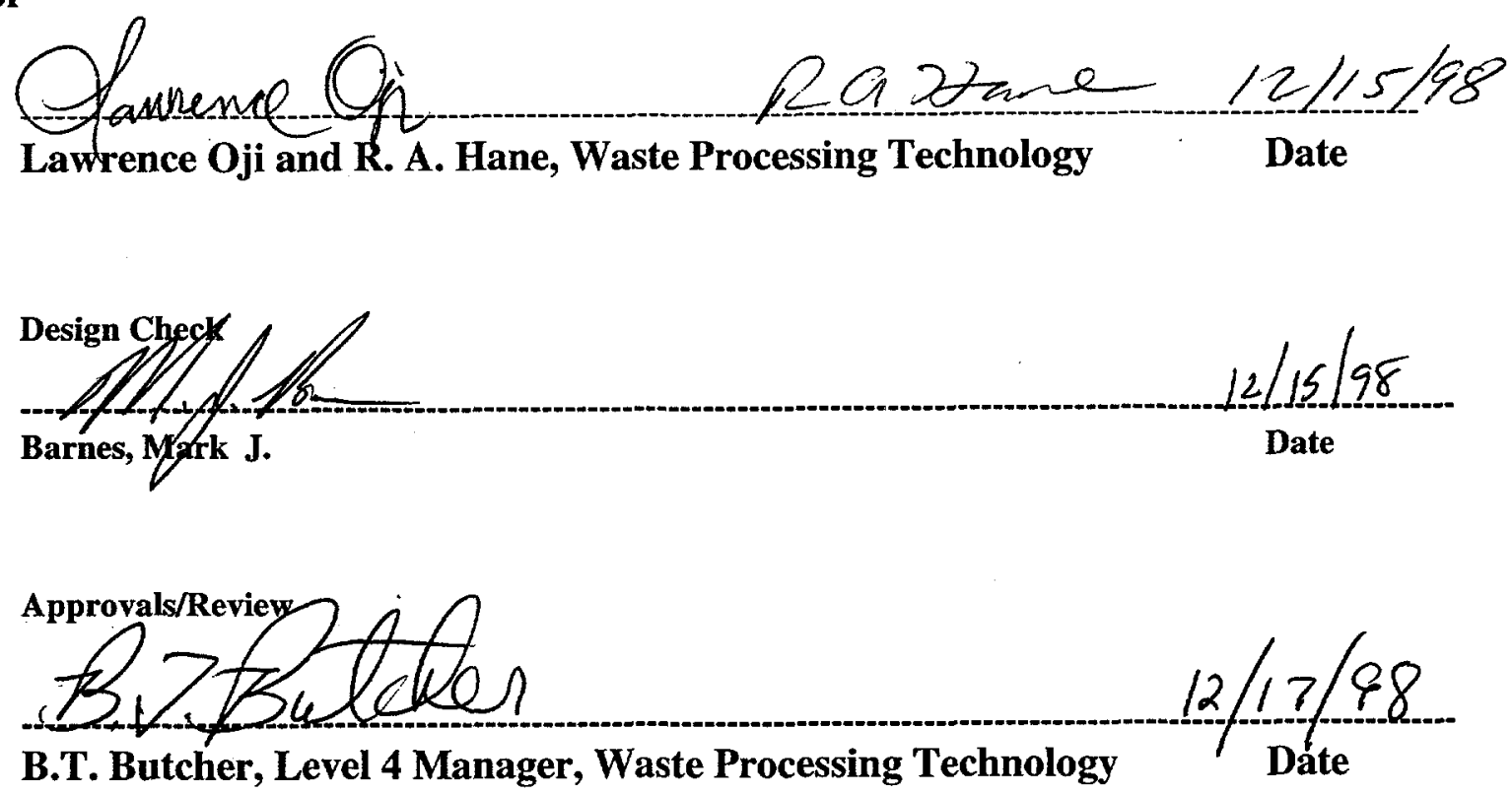

Westinghouse Savannah River Company

Savannah River Site

Aiken, SC 29808

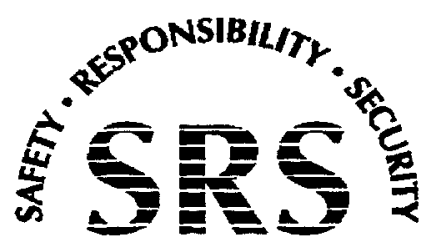




\title{
WESTINGHOUSE SAVANNAH RIVER COMPANY SAVANNAH RIVER TECHNOLOGY CENTER
}

\author{
Keywords: Outfall \\ Sump water \\ IX Column
}

\section{ION EXCHANGE CONCEPTUAL DESIGN FOR TREATING SEVEN TECHNICAL AREA SUMPS WITH ELEVATED LEVELS OF COPPER AND ZINC (U)}

\section{SUMMARY}

Recently a meeting was held to discuss technical support for developing a conceptual design and estimate for installing and operating an in-line ion exchange system to treat seven Technical Area sumps with elevated levels (high ppb - low ppm) of copper and potentially zinc (copper level is above the outfall limits). These sump waters are currently routed to the A01 outfall, which is permitted by the State of South Carolina. A study of potential treatment options and followup laboratory work done in the summer of 1997 by Larry Oji and John Hage identified two commercially available ion exchange resins, Duolite GT-73 and Chelex 100, for treating waters at these metals concentrations (Reference 1).

The Environmental Compliance Group in Technical Services Division requested WPT support for a conceptual design and estimate of this treatment option. They are also considering the option of re-routing these sumps to the sanitary sewer system.

The desired upper limit metal concentrations for the ion exchanged treated sump effluent are respectively, $0.022,0.059,0.005$ and $<0.0001 \mathrm{mg} / \mathrm{L}$ for copper, zinc, lead and mercury. The above identified ion exchange resins (Duolite GT-73 and Chelex 100) are expected to meet these desired metal concentration goals for the sump effluents. At a maximum pumping rate of $50 \mathrm{gpm}$ (189.3 L/min.) for each sump pump, a Chelex 100 column resin would need to be changed after processing approximately 616,000 liters $(163,000$ gallons) of sump water (Table 2$)$. The Duolite GT-73 will need to be changed after processing about 155,000 liters ( 41,000 gallons) of water.

These two ion exchange columns, in series, will require a pre-filter unit up stream to remove debris and particulate matter. The depth of the resins inside each column is expected to be greater than 0.6 Liters ( 2 feet).

The retail cost for Chelex 100 is $\$ 0.49$ per gram (Reference 2). Duolite GT-73 is in widespread use at SRS and is thus available for use in this application. A price for Duolite GT-73 has not been obtained for this report. 
WSRC-TR-98-00453

Page 3 of 9

\section{DESIGN APPROACH AND CALCULATIONS}

The attached design calculations are based on two ion exchange columns in series (the first column is Chelex 100 and the second column is Duolite GT-73). These two resins have, in earlier studies, been identified as the most promising ion exchange materials for removing copper/zinc and mercury ions from the A01 outfall (Reference 1). The Chelex 100 column would remove primarily copper and zinc from the sump water. The GT-73 column would remove mercury and lead, and depending on the oxidation state of lead in the water both resins are expected to remove lead (water $\mathrm{pH}=6.5-7.5$ ).

The average concentration of copper, zinc, mercury and lead (respectively, 0.997, 0.154, 0.001 and $0.003 \mathrm{mg} / \mathrm{L}$ ) used in the calculation of resin bed volume requirements are based on information provided by $\mathrm{M}$. Boerste (Attachment $\mathrm{A}$ ). The average concentrations of the principal competing ions (calcium, magnesium, and iron) are respectively, 0.434, 0.073 and $0.089 \mathrm{mg} / \mathrm{L}$ (Attachment A: Table 3 and e-mail from M. Boerste).

Because copper ions are preferentially removed by Chelex 100 over zinc ions, the determination of $50 \%$ breakthrough for column operations and resin cartridge replacement intervals are based on copper batch distribution constants ( $K_{d}$ and column $K_{d}(1)$ ), where the column $K_{d}, \lambda$, is equal to the product of the batch distribution constant and the bulk density $(\rho)$ of the ion exchange material $\left(\lambda=K_{d} * \rho\right)$. This parameter represents the theoretical number of bed volumes that can be processed. Batch distribution constants for the ions, as measured in the laboratory (Reference 1), are summarized in Table 1.

Based on a nominal total capacity of $0.7 \mathrm{meq} / \mathrm{mL}$ for Chelex 100 resin and a maximum pumping rate of $50 \mathrm{gpm}(189.3 \mathrm{~L} / \mathrm{min}$.) for each sump pump, a Chelex 100 column resin would need to be changed after processing 616,000 liters (163,000 gallons) of sump water (Table 2). The Duolite GT-73 will need to be changed after processing about 155,000 liters $(41,000$ gallons) of water.

Neither column is a mixed bed. It is advisable to install a pre-filter upstream of the Chelex 100 column to trap particulates. The Duolite GT-73 column is to be installed downstream of the Chelex 100 column. The pre-filter and two ion exchange columns are to be installed in series. They should be installed in a vertical or horizontal configuration and should not be installed at an angle greater than 15 degrees from the vertical or horizontal, respectively, to prevent channeling effect in the resin bed. It is advisable to provide a reservoir between the sump and the columns to maintain constant moisture content in the resin beds. Because the calculations were done conservatively, this is not, however, required. A water drip arrangement to keep the beds moist between pumpings is another alternative, but again is not required. The depth of resin in each column should be greater than $0.61 \mathrm{~L}(2 \text { feet })^{\mathrm{A}}$. For other column dimensions see resin bed volumes (BV) as summarized in Table 2.

The spent resin should not be regenerated because of the remote possibility of resins trapping and concentrating traces of radionuclides. The resin beds are not composed of F-listed or hazardous chemicals. However, because they may be concentrating RCRA metals $(\mathrm{Hg}, \mathrm{Pb})$ they likely will require disposal as mixed-Low Level Waste.

\footnotetext{
${ }^{A}$ Industrial standard.
} 


\section{Design Calculations}

Chelex 100 resin capacity to remove copper and zinc ions, from each sump water reservoir in the presence of $\mathrm{Ca}, \mathrm{Mg}$, and $\mathrm{Fe}$ as competing ions.

A) Concentration of important sump water ions ${ }^{B}:[\mathrm{Cu}]=0.997 \mathrm{mg} / \mathrm{L}$; target ion

$[\mathrm{Zn}]=0.154 \mathrm{mg} / \mathrm{L}$, target ion

$[\mathrm{Ca}]=0.434 \mathrm{mg} / \mathrm{L}$; competing ion

$[\mathrm{Mg}]=0.073 \mathrm{mg} / \mathrm{L}$; competing ion

$[\mathrm{Fe}]=0.089 \mathrm{mg} / \mathrm{L}$; competing ion

Sump water $\mathrm{pH}=$ near neutral $(6.5-7.5)$

B) Chelex 100 data:

$$
\begin{array}{ll}
\text { - Moisture content } & =71-76 \% \\
\text { - Wet mesh range } & =100-200 \text { spherical } \\
\text { - Nominal total capacity } & =0.7 \mathrm{meq} / \mathrm{mL} \text { resin bed; } 2.9 \mathrm{meq} / \mathrm{dry} \text { bed } \\
\text { - Bulk density } & =0.65 \mathrm{~g} / \mathrm{mL}
\end{array}
$$

C) Total weight of metal ions in a typical sump pump output volume per $24 \mathrm{hrs}$. (cycle) ${ }^{\mathrm{C}}$.

Maximum flow rate $=\mathbf{5 0} \mathrm{gpm}$

Maximum volume of water processed by each sump pump per cycle $=50$ gallons $/ \mathrm{min} * 60 \mathrm{~min} / \mathrm{hr}$. ${ }^{*} 24$ hours/cycle*3.785 Liters/gallon $=272,500$ Liters/cycle.

- Total concentration of metal ions $=1.747 \mathrm{mg} / \mathrm{L}$

- Average mole. wt. of relevant metal ions ( $\Sigma^{\mathrm{n}}$ gram

formula $w \mathrm{t}$.) $/ \mathrm{n}=$ average molecular $\mathrm{wt} .=40.971 \mathrm{~g} / \mathrm{mole}$ (an approximation)

-Total wt of metal ions $=(1.747 \mathrm{mg} / \mathrm{L}) * 272,500 \mathrm{~L} /$ cycle $=476.06 \mathrm{~g} /$ cycle

D) Weight of total metal to equivalence (average equivalent is $11 / 5=2.2$ )

- (Total wt of metal ions)/(Average mo. wt.)/2eq/gmw $=$

$476.06(\mathrm{~g} / \mathrm{cycle})) /(40.971(\mathrm{gmw})) /(2.2 \mathrm{eq} / \mathrm{gmw})=5.282 \mathrm{eq} / \mathrm{cycle}$

E) Daily needed capacity

- Calculated capacity/ Chelex 100 wet capacity $=$

$5.282 \mathrm{eq} / \mathrm{cycle} / 0.0007 \mathrm{eq} / \mathrm{mL}=7,545.05 \mathrm{~mL}$

$\approx 7.545$ Liters of Chelex $100=$ One Bed Volume (BV)

F) Weight of Chelex 100

- capacity volume ((liters/cycle)*( Chelex 100 density)) $=$

7.545 Liters * $0.65 \mathrm{~kg} / \mathrm{Liter}=4.904 \mathrm{~kg}(10.79 \mathrm{lbs})$.

At an average of 14.21 gallons per minute processing rate the volume of resin (BV) would equal 2.144 Liters of Chelex 100 or $1.395 \mathrm{Kg}(3.07 \mathrm{lbs})$.

\footnotetext{
${ }^{B}$ Divalent and trivalent competing ions with concentrations greater than $0.001 \mathrm{mg} / \mathrm{L}$.

${ }^{c}$ Typical industrial length of service run (between resin regeneration) for automated ion exchange facility is 8 hours.
} 
Duolite GT-73 capacity to remove mercury, copper and zinc ions from each sump water reservoir in the presence of $\mathrm{Ca}, \mathrm{Mg}$, and $\mathrm{Fe}$ as competing ions.

The first IX column (Chelex 100) will primarily remove copper and zinc from the sump water. The second IX column (GT-73) will remove the other ions of importance (mercury and lead). Competing ions (calcium, magnesium and iron) are expected to play a major role in the efficiency of both columns. Calculations have taken these into account.

A) Concentration of important sump water ions

$$
\begin{aligned}
& {[\mathrm{Hg}]=0.001 \mathrm{mg} / \mathrm{L} ; \text { target ion }} \\
& {[\mathrm{pb}]=0.003 \mathrm{mg} / \mathrm{L} ; \text { target ion }} \\
& {[\mathrm{Ca}]=0.434 \mathrm{mg} / \mathrm{L} ; \text { competing ion }} \\
& {[\mathrm{Mg}]=0.073 \mathrm{mg} / \mathrm{L} ; \text { competing ion }} \\
& {[\mathrm{Fe}]=0.089 \mathrm{mg} / \mathrm{L} ; \text { competing ion }}
\end{aligned}
$$

B) GT-73 data:

- Nominal total capacity $=0.7 \mathrm{meq} / \mathrm{mL}$ resin bed

- $\quad$ Bulk density $=0.69 \mathrm{~g} / \mathrm{mL}$

C) Total weight of metal ions in sump pump water per $24 \mathrm{hrs}(\text { cycle })^{\mathrm{C}}$

- Maximum volume of sump pump water processed per cycle $=\mathbf{2 7 2 , 5 0 0}$ Liters/cycle.

- Total concentration of metal ion $=0.6 \mathrm{mg} / \mathrm{L}$

- Average mole. wt. of relevant metal ions ( $\Sigma^{\mathrm{n}}$ gram formula wt.)/n = average molecular wt. $=105.60 \mathrm{~g} /$ mole (an approximation)

- Total wt of metal ions $=(0.6 \mathrm{mg} / \mathrm{L}) * 272,500$ Liters $/$ cycle $=163.5 \mathrm{~g} / \mathrm{cycle}$.

D) Weight of total metal to equivalence (average equivalent is $10 / 5=2$ )

- (Total wt of metal ions $) /($ Average mo. wt. $) / 2 \mathrm{eq} / \mathrm{gmw}=$ $(163.5(\mathrm{~g} / \mathrm{cycle})) /(105.60(\mathrm{gmw})) /(2 \mathrm{eq} / \mathrm{gmw})=0.774 \mathrm{eq} / \mathrm{cycle}$

E) Daily needed capacity

F) Weight of GT-73

$$
\begin{aligned}
& \text { - Calculated capacity/ GT-73 wet capacity }= \\
& 0.774 \text { eq/cycle } / 0.0007 \mathrm{eq} / \mathrm{mL}=1105.93 \mathrm{~mL} \\
& \mathbf{1 . 1 0 6} \text { liters of GT-73) }=\text { One Bed Volume (BV) }
\end{aligned}
$$

- capacity volume ((liters/cycle)*( GT-73 density)) $=$

1.106 Liters $/$ cycle $* 0.69 \mathrm{~kg} /$ Liter $=0.763 \mathrm{~kg}$ of GT $-73(1.678 \mathrm{lbs})$.

At an average of 14.21 gallons per minute processing rate the volume of resin (BV) would equal 0.314 Liters of Duolite GT-73 or $0.217 \mathrm{Kg}(0.477 \mathrm{lbs})$. 


\begin{tabular}{|l|l|l|l|l|l|l|l|}
\hline Resin Type & $\mathbf{C u}$ & $\mathbf{Z n}$ & $\mathbf{C a}$ & $\mathbf{M g}$ & $\mathbf{F e}$ & $\mathbf{H g}$ & $\mathbf{P b}$ \\
\hline Chelex -100 & 81,600 & 65.800 & $1.35 \mathrm{E} \mathrm{07}$ & $2.55 \mathrm{E} 07$ & 12,600 & $\begin{array}{l}\text { Not } \\
\text { determined }\end{array}$ & Not determined \\
\hline & & & & & & & \\
\hline Duolite GT-73 & 53,000 & 6,500 & $1.45 \mathrm{E} \mathrm{04}$ & 560 & 1,600 & $\begin{array}{l}\text { Resin designed } \\
\text { primarily for } \\
\text { Hg removal. }\end{array}$ & $\begin{array}{l}\text { Not determined, } \\
\text { but known to be } \\
\text { removed by this } \\
\text { resin. }\end{array}$ \\
\hline
\end{tabular}

Table 1. Average batch distribution constants $\left(K_{d}\right)$ for target ion and competing ions (ml/g) (Reference 1)

\begin{tabular}{|l|l|l|l|}
\hline Resin Type & $\begin{array}{l}\text { Resin BV for Columns } \\
\text { in series: Sump flow } \\
\text { rate of 14.21 gpm }\end{array}$ & $\begin{array}{l}\text { Resin BV for Column in } \\
\text { series: Sump flow rate of 50 } \\
\text { gpm }\end{array}$ & $\begin{array}{l}\text { Maximum volume processed } \\
\text { Before 50\% breakthrough } \\
\text { for Cu, Zn and } \mathbf{~ H g} . \\
\left(\lambda=\mathrm{K}_{\mathrm{d}} \rho\right) \mathrm{BV}\end{array}$ \\
\hline & & & \\
\hline Chelex 100 & $2.144 \mathrm{~L}(3.07 \mathrm{lbs})$ & $7.545 \mathrm{~L}(10.79 \mathrm{lbs})$ & $615,672 \mathrm{~L}$ (copper) \\
\hline & & & $496,461 \mathrm{~L}(\mathrm{zinc})$ \\
\hline & & & \\
\hline Duolite GT-73 & $0.314 \mathrm{~L}(0.45 \mathrm{lbs})$ & $1.106 \mathrm{~L}(1.58 \mathrm{lbs})$ & $154,840 \mathrm{~L}$ (mercury) \\
\hline & & & \\
\hline
\end{tabular}

Table 2. Summary of bed volume (BV)and maximum processed volumes based on copper, zinc and mercury $K_{d}$ values

\section{References}

(1) L N. Oji and J. P. Hage, “ Copper removal from A-01 Outfall by ion-exchange (U)" WSRC-RP-97-767. September 18, 1997.

(2) Bio-Rad bulletin \# 1224, Bio-Rad, Chemical Division, 2200 Wright Avenue, Richmond, Ca. 94804 (415-234-4130 or 1-800-4-BioRad).

${ }^{D}$ Based on estimated mercury batch distribution constant $\left(\mathrm{K}_{\mathrm{d}}\right)$ value of $140,000 \mathrm{ml} / \mathrm{g}$. 


\section{ATTACHMENT A}

\section{Meeting minutes}

Subject: Support to Environmental Compliance on Sump Water Treatment Author: Tom Butcher at SRCCA13

Date: $10 / 9 / 98$ 11:23 AM

A meeting was held on Wednesday, 10/7, to discuss technical support for developing a conceptual design and estimate for installing and operating an in-line ion exchange system to treat seven Technical Area sumps with elevated levels (high ppb - low ppm) of copper, lead, mercury, zinc and iron. These sumps are currently routed to the A01 outfall which is permitted by the State. Copper level are above the outfall limits. A study of potential treatment options and followup labwork done in summer 1997 by John Hage and Larry Oji identified two commercially available ion exchange resins, Duolite GT-73 and Chelex 100, for treating waters at these metals concentrations. The Environmental Compliance Group in Technical Services Division is requesting WPT support for a conceptual design and estimate of this treatment option. They are also considering the option of re-routing these sumps to the sanitary sewer system. Those on distribution were in attendance. The following items were discussed and actions identified:

- Stan Harmon will be the point of contact for receiving all design input infomation. Stan is preparing a request to Bectel to do the conceptual design and estimate for both the treatment and sanitary sewer options.

- Mike Boerste is the lead on the overall effort and will provide treatment goals and other environmental considerations.

- Spent resin will be disposed and not regenerated. Treatment must not result in generation of hazardous secondary waste.

- Richard Hane will provide engineering input to Stan. Information needed for design includes: size of columns, flow rate requirements, configuration of beds, resin replacement requirements, disposal requirements, etc.

- Larry Oji will consult with Richard on chemistry requirements such as single or mixed bed IX, time to breakthrough at given metals concentrations, competitive ion effects, need for prefiltering, etc.

- All design input will be gathered and turned over to Stan Harmon two weeks from receipt of activity code

- Gordon Hayford will provide the activity code to WPT for this effort

Please contact me at $\times 5-5810$ if you have any questions. 
E-Mail communications: Author: Michael Boerste at SRCCA07

The second round of sump data is in. Here are both sets for your use in development of the ion exchange treatment option.

\begin{tabular}{|c|c|c|c|c|c|c|}
\hline $\begin{array}{l}\text { Condensate Sump } \\
\text { Location }\end{array}$ & $\begin{array}{l}\text { Dates } \\
\text { Sampled }\end{array}$ & $\begin{array}{l}\text { [Copper] } \\
\mathrm{mg} / \mathrm{L}\end{array}$ & $\begin{array}{l}\text { [Iron] } \\
\mathrm{mg} / \mathrm{L}\end{array}$ & $\begin{array}{l}\text { [Lead] } \\
\mathrm{mg} / \mathrm{L}\end{array}$ & $\begin{array}{l}{[\mathrm{Zinc}]} \\
\mathrm{mg} / \mathrm{L}\end{array}$ & $\begin{array}{l}\text { [Mercury] } \\
\mathrm{mg} / \mathrm{L}\end{array}$ \\
\hline 773-A A-wing & $8 / 10 / 98$ & 0.443 & 0.086 & 0.011 & 0.045 & $<0.0001$ \\
\hline 773-A A-wing & $10 / 2 / 98$ & 0.147 & 0.166 & $<0.003$ & 0.022 & $<0.0001$ \\
\hline 773-A C-wing W & $8 / 10 / 98$ & 1.07 & $<0.020$ & $<0.003$ & 0.062 & 0.0001 \\
\hline 773-A C-wing $W$ & $10 / 2 / 98$ & 0.386 & 0.058 & $<0.003$ & 0.024 & $<0.0001$ \\
\hline 773-A C-wing SE & $8 / 10 / 98$ & 2.04 & 0.037 & $<0.003$ & 0.093 & 0.0003 \\
\hline 773-A C-wing SE & $10 / 2 / 98$ & 0.851 & 0.079 & 0.003 & 0.041 & $<0.0001$ \\
\hline 773-A B-wing SE & $8 / 10 / 98$ & 2.19 & 0.143 & $<0.003$ & 0.138 & 0.0002 \\
\hline 773-A B-wing SE & $10 / 2 / 98$ & 1.17 & 0.21 & $<0.003$ & 0.131 & $<0.0001$ \\
\hline 773-A B-wing W & $8 / 10 / 98$ & 1.6 & 0.076 & $<0.003$ & 0.077 & $<0.0001$ \\
\hline 773-A B-wing $W$ & $10 / 2 / 98$ & 0.616 & 0.073 & $<0.003$ & 0.1 & $<0.0001$ \\
\hline 773-A B-wing NE & $8 / 10 / 98$ & 1.52 & 0.134 & $<0.003$ & 0.133 & 0.0001 \\
\hline 773-A B-wing NE & $10 / 2 / 98$ & 1.43 & 0.029 & $<0.003$ & 0.124 & $<0.0001$ \\
\hline 735-A A-Wing & $8 / 10 / 98$ & 0.254 & 0.077 & 0.032 & 0.092 & $<0.0001$ \\
\hline 735-A A-Wing & $10 / 2 / 98$ & 0.238 & 0.078 & 0.01 & 0.081 & $<0.0001$ \\
\hline Average concentration & & 0.997 & 0.089 & 0.003 & 0.154 & 0.0001 \\
\hline
\end{tabular}

Table 3. Metal concentrations in sump water.

EPD anticipats (sic) any zinc limit will be above $200 \mathrm{mg} / \mathrm{L}$, which is higher than all the sump values. Zinc removal should therefore be considered just a bonus. Please focus on Copper, Lead and Mercury. This may make GT-73 alone more attractive since it may last longer for the target ions, taking up less iron, zinc and water hardness metals $(\mathrm{Ca} / \mathrm{Mg})$, and it's already widely used on site. Please consider this as well as a mixed bed.

Reply Separator

Author: Michael Boerste at SRCCA07

Date: $10 / 7 / 98$ 4:06 PM

Copper and lead have outfall permit limits as follows. Mercury has a limit below detection so the mandated detection limit is listed. Zinc is only anticipated for a limit so I have provided a water quality standard as a very conservative first approximation. (Iron has no limit and is not anticipated to get one.) Please consider these as desired upper bounds for ion exchanged sump effluent.

Copper $(\mathrm{Cu}) 0.022 \mathrm{mg} / \mathrm{L}$

Lead $(\mathrm{Pb}) 0.005 \mathrm{mg} / \mathrm{L}$

Mercury $(\mathrm{Hg})<0.0001 \mathrm{mg} / \mathrm{L}$

Zinc ( $\mathrm{Zn}) \quad 0.059 \mathrm{mg} / \mathrm{L}$ 
$\forall \mathcal{E}$ - $\mathcal{L} L L$ 'spıoэәy LdM

$\forall \varepsilon t-\varepsilon L L$ 'our $\mathrm{H} \cdot \mathrm{V} \cdot \mathrm{d}$

$\forall-\varepsilon L L$ 'suәләI ' $\forall Z S-\varepsilon L L '(t)$ spıoooy JLdS $\forall \varepsilon \nabla-\varepsilon L L$ '! $\left[\mathrm{O}^{\circ} \mathrm{N}\right\urcorner$ $\forall-\varepsilon L L$ ' "uowue ${ }^{\prime} W$ 'S $\forall Z \varsigma-\varepsilon L L(t)$ WIL

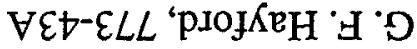

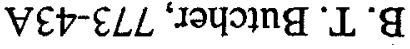

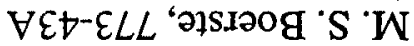
:uo!̣nq!.I?

ino 00 *

\begin{tabular}{|c|c|c|c|c|c|c|c|c|c|c|c|c|c|c|}
\hline $1000^{\circ} 0>$ & $180^{\circ} 0$ & $9^{\prime} \mathrm{ZL}$ & $900^{\circ} 0>$ & $7 \div 21$ & $010.0>$ & $\angle \angle L^{\circ} 0$ & 10.0 & $8 \angle 0^{\circ} 0$ & $8 \varepsilon Z^{\circ} 0$ & $900.0>$ & $229 \cdot 0$ & $090^{\circ} 0>$ & $86 / 2 / 01$ & Gu!M- $\forall \forall-s \varepsilon<[L]$ \\
\hline $1000.0>$ & $260^{\circ} 0$ & .0 .01 & $900^{\circ} 0>$ & $9 \cdot 01$ & $010.0>$ & $090^{\circ} 0>$ & $280^{\circ} 0$ & $\angle \angle O^{\circ} 0$ & $\forall 9 Z^{\circ} 0$ & $010.0>$ & $9 t t^{\circ} 0$ & $090^{\circ} 0>$ & $86 / 01 / 8$ & 6u! $M-\forall \forall-\varsigma \varepsilon<[L]$ \\
\hline $1000^{\circ} 0^{>}$ & $D 2 L \cdot 0$ & $0010>$ & $5000^{\circ}>$ & $0020>$ & $010^{\circ} 0>$ & $090^{\circ} 0>$ & $\varepsilon 00^{\circ} 0>$ & $620^{\circ} 0$ & $E t^{\circ} \cdot$ & $900^{\circ} 0>$ & $6 S 1^{\circ} 0$ & $2+1 \cdot 0$ & $86 / 2 / 01$ & $\exists N$ bu!M-g $\forall-\varepsilon L L[9]$ \\
\hline $1000^{\circ} 0$ & $\varepsilon \varepsilon L^{\circ} 0$ & $* \angle 180^{\circ}$ & $900^{\circ} 0>$ & $0020>$ & $0100>$ & $090.0>$ & $800^{\circ} 0>$ & $t \varepsilon 1 \cdot 0$ & $29 \cdot 1$ & $010.0>$ & $62 Z^{\prime} 0$ & $181^{\circ} 0$ & $86 / 0 \mathrm{l} / 8$ & $\exists N$ bu!M-g $\forall-\varepsilon L L[9]$ \\
\hline $1000^{\circ} 0>$ & 1.0 & $81^{\circ} 0$ & 90007 & $\angle 9+0$ & 01007 & $280^{\circ} 0$ & $\varepsilon 00^{\circ} 0>$ & $\varepsilon \angle 0^{\circ} 0$ & 9190 & $0100>$ & $91 \cdot 1$ & $090^{\circ} 0>$ & $86 / 2 / 01$ & $M$ Gu!M-g $\forall-\varepsilon L L[g]$ \\
\hline $10000>$ & $\angle \angle 0^{\circ} 0$ & $\times 219^{\circ} 0$ & $900^{\circ} 0>$ & $0020>$ & $0100>$ & $090^{\circ} 0>$ & $800^{\circ} 0>$ & $9 \angle 0^{\circ} 0$ & $9 \%$ & $010^{\circ} 0>$ & SSt0 0 & $090^{\circ} 0>$ & $86 / 01 / 8$ & $M$ Gu!M-g $\forall-\varepsilon L L[s]$ \\
\hline $1000.0>$ & LEL'O & $861^{\circ} 0$ & $S 00^{\circ} 0>$ & $81 \varepsilon^{\circ} 0$ & $0100>$ & $090^{\circ} 0>$ & $800^{\circ} 0>$ & $\angle Z^{\prime} 0$ & $\angle H \cdot$ & $900^{\circ} 0>$ & $001.0>$ & $090^{\circ} 0>$ & $86 / 2 / 01$ & $\exists S$ 6u!M-g $\forall-\varepsilon L L[t]$ \\
\hline $2000^{\circ} 0$ & $8 \varepsilon 1^{\circ} 0$ & $.069^{\circ} 0$ & $900^{\circ} 0^{>}$ & $002^{\prime} 0>$ & $010^{\circ} 0>$ & $090.0>$ & $800^{\circ} 0>$ & $\varepsilon+l^{\circ} 0$ & $61^{2} 2$ & $0100>$ & $0010>$ & $090^{\circ} 0>$ & $86 / 01 / 8$ & $\exists S$ Gu!M-g $\forall-\varepsilon L L[b]$ \\
\hline $1000^{\circ} 0>$ & $1+0.0$ & $0010>$ & $+10^{\circ} 0$ & $0020>$ & $0100>$ & $090^{\circ} 0>$ & $800^{\circ} 0$ & $6 \angle 0^{\circ} 0$ & $198^{\circ} 0$ & $900^{\circ} 0>$ & $\varepsilon+9^{\circ} 0$ & $090^{\circ} 0>$ & $86 / 2 / 01$ & $\exists S$ 6u!M-O $\forall-\varepsilon \angle L[\varepsilon]$ \\
\hline$\varepsilon 000^{\circ} 0$ & $860^{\circ} 0$ & $* \nabla \varepsilon 9^{\circ} 0$ & $900^{\circ} 0>$ & $002: 0>$ & $0100>$ & $0900>$ & $\varepsilon 00^{\circ} 0>$ & $\angle 80^{\circ} 0$ & $50^{\prime} \mathrm{Z}$ & $0100>$ & 6LE'O & $090^{\circ} 0>$ & $86 / 0 \mathrm{~L} / 8$ & $\exists S$ бu!M-Ј $\forall-\varepsilon \angle L[\varepsilon]$ \\
\hline $1000^{\circ} 0>$ & $\$ 20^{\circ} 0$ & $20 \circ$ & $900^{\circ} 0>$ & टहट०0 & $010.0>$ & $9 \angle 0^{\circ} 0$ & $\varepsilon 00^{\circ} 0>$ & $890^{\circ} 0$ & $98 \varepsilon^{\circ} 0$ & $900^{\circ} 0>$ & $+82^{\prime} 0$ & $0 S 0>$ & $86 / 2 / 01$ & $M$ бu!M-O $\forall-\varepsilon \angle L[Z]$ \\
\hline 10000 & $290^{\circ} 0$ & $.6 t^{\circ} \varepsilon$ & $500^{\circ} 0>$ & $002.0>$ & $0100>$ & $0900^{\circ}>$ & $800^{\circ} 0>$ & $020^{\circ} 0>$ & $20 \%$ & $010^{\circ} 0>$ & $82 \angle 0$ & $090^{\circ} 0>$ & $86 / 0 \mathrm{~L} / 8$ & $M$ bu!M-つ $\forall-\varepsilon L L[z]$ \\
\hline $1000^{\circ} 0>$ & $220^{\circ} 0$ & $2 " 21$ & $900^{\circ} 0>$ & $t \varepsilon .0$ & $010^{\circ} 0>$ & $\varepsilon 81^{\circ} 0$ & $800^{\circ} 0>$ & $991 \cdot 0$ & $\angle D 10$ & $900^{\circ} 0>$ & $2 \angle t \cdot 0$ & $090^{\circ} 0>$ & $86 / 2 / 01$ & $6 u ! M-\forall \forall-\varepsilon L L[t]$ \\
\hline $1000 \%$ & $9+0.0$ & $+99^{\circ} 6$ & $500^{\circ} 0>$ & $002^{\prime} 0>$ & $010.0>$ & $090.0>$ & 1100 & $980^{\circ} 0$ & $\varepsilon+t^{\circ} 0$ & $010.0>$ & ESS:0 & $090.0>$ & $86 / 01 / 8$ & 6u!M- $\forall \forall-\varepsilon L L[t]$ \\
\hline Kunosew & ou!z & un!pos & Lan!!S & un!sseiod & |өYग!N & un!soubew & peo7 & nod & jeddoo & un!modyo & un!ojeo & unu!̣un| $\forall$ & әəॄе & uoṇeooj duns \\
\hline
\end{tabular}

|/6ur 'sduns ә̨еsuəpuog u! sןęəw

$6 \mathrm{~J} 06{ }^{28 \mathrm{e}_{\mathrm{d}}}$

ESt00-86-\&L-J\&SM 